\title{
Efektivitas Pemberian Ekstrak Buah Kersen (Muntingia calabura) terhadap Rasio Berat Testis pada Tikus yang Dipapar Asap Rokok
}

\author{
Effectiveness of Giving Cherry Fruit Extract (Muntingia calabura) to the Testicular Weight Ratio of \\ Mice Exposed to Cigarette Smoke
}

\author{
Ika Dyah Kurniati ${ }^{1}$, Dyah Mustika Nugraheni ${ }^{1}$ \\ ${ }^{1}$ Staf Pengajar Fakultas Kedokteran Universitas Muhammadiyah Semarang \\ *Penulis Korespondensi. Email: ika@unimus.ac.id
}

\begin{abstract}
Abstrak:
Latar Belakang: Reactive Oxygen Species (ROS) merupakan salah satu mediator terjadinya infertilitas. Produksi ROS akan meningkat dengan adanya polusi udara dan merokok. Polynuclear Aromatic Hydrogen (PAH) yang terkandung dalam asap rokok dapat menyebabkan atrofi testis, menghambat spermatogenesis, dan merusak morfologi spermatozoa. Apabila terjadi kerusakan atau atrofi sel-sel penyusun tubulus seminiferus akan terjadi penurunan berat testis. Buah kersen mengandung senyawa antioksidan yang dapat meningkatkan kualitas sperma. Tujuan penelitian ini adalah untuk mengetahui efek proteksi ekstrak buah kersen terhadap kerusakan testis tikus Sprague dawley yang terpapar asap rokok. Metode: Tikus sejumlah dibagi 4 kelompok, kemudian di papar asap rokok 7 batang perhari dan ekstrak buah kersen (EBK) selama 4 minggu. Kelompok pertama sebagai kontrol (K1) diberi plasebo, kelompok kedua (K2) dipapar asap rokok saja, sedangkan sisanya merupakan kelompok Perlakuan 1 (P1) diberi EBK 100mg/kgBB/hari dan Perlakuan 2 (P2) diberi EBK 200mg/kgBB/hari. Rasio berat testis di analisis dengan uji statistik parametrik One Way ANOVA Test dilanjutkan analisa Post Hoc Multiple Comparison Test.

Hasil: Rasio berat testis pada kelompok kontrol (K1) sejumlah $(0,31)$ kelompok perlakuan 1 (P1) sejumlah $(0,24)$ dan kelompok perlakuan $2(\mathrm{P} 2)$ sejumlah $(0,28)$ sedangkan yang terendah yaitu pada kelompok kontrol paparan asap rokok (K2) sejumlah $(0,19)$. Walaupun terdapat peningkatan rasio berat testis pada tikus yang diberikan ekstrak buah kersen, namun secara statistik perbedaan tersebut tidak bermakna.
\end{abstract}

Kesimpulan: Pemberian ekstrak buah kersen dapat meningkatkan rasio berat testis pada tikus yang di papar asap rokok.

Kata Kunci: asap rokok, buah kersen, antioksidan, rasio berat testis.

\begin{abstract}
:
Background: Reactive Oxygen Species (ROS) is one of the mediators of infertility. ROS production will increase with air pollution and smoking. Polynuclear Aromatic Hydrogen (PAH) contained in cigarette smoke can cause testicular atrophy, inhibit spermatogenesis, and damage the morphology of spermatozoa. If there is damage or atrophy of the cells making up the seminiferous tubules, there will be a decrease in testicular weight. Cherry fruit contains antioxidant compounds that can improve sperm quality. The purpose of this study was to determine the protective effect of cherry fruit extract on testicular damage to Sprague Dawley rats exposed to cigarette smoke.

Method: Mice were divided into 4 groups, then smoked cigarette 7 cigarettes per day and cherry fruit extract (EBK) for 4 weeks. The first group as a control (K1) was given a placebo, the second group (K2) was exposed to cigarette smoke only, while the remaining group Treatment 1 (P1) was given 100mg / kgBB / day EBK and Treatment 2 (P2) was given $200 \mathrm{mg} / \mathrm{kgBB} /$ day EBK. Testicular weight ratio was analyzed by the One Way ANOVA Test parametric test followed by the Post Hoc Multiple Comparison Test analysis.

Result: Testicular weight ratio in the control group (K1) number (0.31) treatment group 1 (P1) number (0.24) and treatment group 2 (P2) number (0.28) while the lowest group control cigarette smoke exposure group (K2) number (0.19). Although there was an increase in the ratio of testicular weight in rats given the Cherry fruit extract, statistically the difference was not significant.
\end{abstract}

Conclusion: Giving cherry fruit extract can increase the testis weight ratio in rats exposed to cigarette smoke.

Keywords: cigarette smoke, cherry fruit, antioxidants, testicular weight ratio. 


\section{PENDAHULUAN}

Menurut data WHO, Indonesia merupakan negara ketiga setelah Cina dan India yang memiliki jumlah perokok aktif terbanyak di dunia yaitu sebesar 61,4 juta perokok. Perilaku merokok penduduk Indonesia cenderung meningkat dari $34,2 \%$ pada tahun 2007 menjadi 36,3\% pada tahun 2013. ${ }^{1}$ Dalam setiap hisapan rokok, terdapat 1014 radikal bebas dan dapat dipertahankan dalam waktu yang relatif lama (>10 menit). Asap rokok tersebut merupakan oksidan yang dapat menghilangkan antioksidan intraseluler dalam sel dan berhubungan dengan mekanisme peningkatan stres oksidatif. ${ }^{2-5}$

Reactive Oxygen Species (ROS) yang menjadi salah satu mediator terjadinya infertilitas. Produksi ROS akan meningkat dengan adanya pengaruh dari lingkungan dan faktor gaya hidup seperti polusi udara dan merokok. Polynuclear Aromatic Hydrogen (PAH) yang terkandung dalam asap rokok dapat menyebabkan atrofi testis, menghambat spermatogenesis, dan merusak morfologi spermatozoa, sedangkan paparan nikotin menyebabkan penurunan kadar hormon testosteron melalui mekanisme penghambatan fungsi sel Leydig yang berfungsi sebagai sekretor hormon testosteron. ${ }^{6}$

Testis merupakan organ genital yang dapat memproduksi spermatozoa dan hormon seks. Di dalam testis terdapat tubulus seminiferus, jaringan ikat dan pembuluh darah. Tubulus seminiferus merupakan komponen penyusun testis yang terbesar. Apabila terjadi kerusakan atau atrofi sel-sel penyusun tubulus seminiferus akan terjadi penurunan berat testis. Testis yang mengalami kelainan akan dapat mempengaruhi proses spermatogenesis yang dapat mempengaruhi terjadinya penurunan kualitas spermatozoa. Berat testis dapat dianalisis dengan menimbang testis kanan dan kiri. Parameter berat organ merupakan indikator yang baik untuk menunjukkan aktivitas pertumbuhan sel dan aktivitas sekresi endokrin. ${ }^{7}$
Untuk mencegah dampak buruk akibat senyawa radikal penyebab kerusakan sel, dibutuhkan antioksidan yang dapat berasal dari tubuh sendiri maupun dari luar. Dari dalam tubuh akan dibentuk senyawa untuk menetralisir antara lain SOD (superoksid dismutase). Sedangkan dari luar antara lain dari makanan dimana mengandung zat antioksidan yang digunakan sebagai pemutus rantai (chain-breaking antioxidant) yaitu vitamin $\mathrm{C}$, vitamin $\mathrm{E}$, beta karoten, dan golongan flavonoid..$^{8,9}$

Buah kersen (Muntingia calabura Linn) adalah buah yang banyak tumbuh di Indonesia, namun masyarakat belum banyak mengetahui manfaat dari buah kersen dan menyebabkan banyaknya buah kersen yang tidak digunakan manfaatkan terutama dibidang kesehatan. Buah kersen (Muntingia calabura Linn) memiliki aktivitas antioksidan yang kuat karena kandungan asam askorbat (vitamin C) yang tinggi, vitamin A dan juga mineral seperti kalsium dan fosfor. Kandungan vitamin $\mathrm{C}$ buah kersen $(379,75 \mathrm{mg}) 3 \mathrm{x}$ lipat dari buah mengkudu (175mg). Dosis lethal ekstrak buah kersen adalah $1000 \mathrm{mg} / \mathrm{kg}$. Hasil ekstrak polifenol buah kersen menunjukkan bahwa buah kersen mengandung antioksidan antara lain Vitamin C (33,6mg AAE/g ekstrak), Vitamin E (14,7mg TE/g ekstrak), total fenol (121,1mg GAE/g ekstrak), flavonoid (173,2mg RE/g ekstrak) dan antosianin (82,4mg CGE/g ekstrak). ${ }^{10}$

Adanya kandungan antioksidan pada buah kersen, maka diharapkan dengan pemberian ekstrak buah kersen dapat menurunkan efek oksidan yang disebabkan paparan asap rokok terhadap fungsi organ penghasil sperma, dengan cara pengamatan terhadap bobot testis.

\section{METODOLOGI PENELITIAN}

Penelitian ini merupakan penelitian eksperimental laboratorik dengan rancangan Post Test Only Control Group Desain. Penelitian ini telah mendapatkan persetujuan dari Komisi Etik Penelitian Kesehatan 
(KEPK) Fakultas Kedokteran Universitas Diponegoro dan RSUP Dr.Kariadi Semarang No. 784/EC/FK/RSDK/2016. Tempat penelitian dilakukan di di Laboratorium Unit Pangan dan Gizi Pusat Antar Universitas (PAU) Universitas Gajah Mada (UGM), Laboratorium Patologi Anatomi FK UGM-RS Sardjito Yogyakarta dan Laboratorium Patologi Anatomi FK UNDIP Semarang periode Agustus-Oktober 2016.

\section{Subjek Penelitian}

Hewan coba yang dipakai pada penelitian ini adalah tikus putih jantan galur Sprague-Dawley. Kriteria inklusi adalah umur 2-3 bulan, berat 150-200 gram, sehat. Kriteria eklusi adalah tikus tidak bergerak aktif, terdapat abnormalitas anatomi yang tampak. Kriteria drop out adalah tikus mati. Besar sampel ditentukan berdasarkan rumus $\mathrm{WHO}^{11}$ jumlah sampel setiap kelompok perlakuan minimal 5 ekor tikus tiap kelompok. Antisipasi drop out dilakukan dengan menambahkan 1 tikus pada masing-masing kelompok.

\section{Pembuatan Ekstrak metanol buah kersen (Muntingia calabura)}

Buah kersen segar di blender kemudian diekstrak menggunakan metanol dengan perbandingan 1:3 (jus buah : pelarut) menggunakan orbital shaker pada suhu ruang, kemudian ekstrak di sentrifuge dan supernatan dikumpulkan. Untuk mendapatkan maserat digunakan rotary evaporator pada suhu $40^{\circ} \mathrm{C}$ dilanjutkan dengan diuapkan dengan nitrogen sehingga didapatkan ekstrak buah kersen yang kental dan konsentrasinya mendekati $99 \%$. Dosis ekstrak buah kersen yang dibuat adalah $100 \mathrm{mg} / \mathrm{kg}$ BB dan 200 $\mathrm{mg} / \mathrm{kg}$ yang dilarutkan dalam $\mathrm{Na} \mathrm{CMC} 0,5 \%$ $2 \mathrm{ml} / 200 \mathrm{gr}$ BB.

\section{Protokol Penelitian}

Sampel tikus Sprague-Dawley jantan dibagi menjadi 4 kelompok secara random. Kelompok pertama sebagai kontrol negatif (K1) yang diberikan placebo ( $\mathrm{Na}$ CMC $0,5 \%$ ) tanpa paparan asap rokok kretek tanpa filter 7 batang per hari. Kelompok kedua sebagai kontrol positif (K2) yang diberikan placebo (Na CMC 0,5\%) dan paparan asap rokok kretek tanpa filter 7 batang per hari. Kelompok ketiga yaitu perlakuan satu (P1) yang diberikan ekstrak buah kersen melalui sonde lambung dengan dosis $100 \mathrm{mg} / \mathrm{kg} \mathrm{BB}$ yang dilarutkan dalam $\mathrm{Na}$ CMC $0,5 \%$ $2 \mathrm{ml} / 200 \mathrm{gr}$ BB dan paparan asap rokok 7 batang per hari, dan kelompok keempat sebagai perlakuan dua (P2) yang diberikan ekstrak buah kersen melalui sonde lambung dengan dosis $200 \mathrm{mg} / \mathrm{kg}$ BB yang dilarutkan dalam $\mathrm{Na}$ CMC 0,5\% 2ml/200gr BB dan paparan asap rokok 7 batang per hari. Pemberian ekstrak buah kersen diberikan 30 menit sebelum pemaparan asap rokok. Paparan asap rokok dan pemberian ekstrak buah kersen dilakukan selama 4 minggu. Setelah 4 minggu perlakuan, tikus ditimbang berat badannya kemudian di terminasi dan diambil jaringan testis, setelah itu dilakukan penimbangan kedua testis. Penilaian berat testis diukur dengan menimbang testis kanan dan kiri. Rasio berat testis dihitung dengan menggunakan rumus berikut ini: ${ }^{7}$

$$
\text { Rasio }=\frac{\text { Berat Testis }(\text { gram })}{\begin{array}{c}
\text { Berat badan hewan uji saat } \\
\text { dikorbankan }(\text { gram })
\end{array}}
$$

\section{Analisa Statistika}

Data yang diperoleh diolah dengan program komputer SPSS. Data di uji normalitas data menggunakan uji ShapiroWilk Test. Oleh karena distribusi data normal sehingga digunakan uji beda menggunakan uji statistik parametrik One Way ANOVA Test dilanjutkan analisa Post Hoc Multiple Comparison Test.

\section{HASIL}

Perhitungan rasio berat testis dengan cara menimbang testis kanan dan kiri dibagi dengan berat badan hewan uji saat dikorbankan. Hasil perhitungan rerata berat 
badan dan berat testis pada tiap kelompok sebagaimana pada Tabel 1.

Berdasarkan rerata kenaikan berat badan hewan coba sebelum perlakuan yang terendah pada kelompok kontrol sakit (K2) yaitu dari 201 gram namun setelah perlakuan rerata kenaikan berat badannya hanya 1 gram, sedangkan kelompok yang memiliki rerata kenaikan berat badan yang paling tinggi yaitu kelompok sehat (K1) yaitu sebesar 32 gram. Rerata kenaikan berat badan kelompok P1 sebesar 24 gram sedangkan kelompok P2 sebesar 29 gram. Rerata berat testis yang tertinggi yaitu pada kelompok K1 yaitu sebesar 2,8 diikuti kelompok P2 sebesar 2,7, kelompok P1 sebesar 2,4 dan terendah kelompok K2 sebesar 1,9.

Berdasarkan gambar 1, rasio berat testis tertinggi yaitu pada kelompok kontrol sehat (K1) yaitu 0,031, sedangkan rasio berat testis yang terendah yaitu pada kelompok kontrol sakit (K2) yaitu 0,019.

Berdasarkan tabel 2, pada pemeriksaan rasio berat testis antar kelompok, didapatkan bahwa ada perbedaan secara statistik dengan One Way ANOVA Test didapatkan nilai $\rho=0.013$ pada keempat kelompok. Untuk mengetahui perbedaan tiap - tiap kelompok dilakukan analisa lanjut Post Hoc Multiple Comparison Test.

Hasil dari Post Hoc Multiple Comparison Test menunjukkan bahwa terdapat perbedaan rasio berat testis yang bermakna $(\rho<0.05)$ antara kelompok kontrol sehat (K1) dengan kelompok kontrol sakit (K2), kelompok kontrol sehat (K1) dengan perlakuan 1 (kelompok ekstrak buah kersen $100 \mathrm{mg} / \mathrm{kg} \mathrm{BB} /$ hari), serta antara kelompok kontrol sakit (K2) dengan perlakuan 2 (kelompok ekstrak buah kersen $100 \mathrm{mg} / \mathrm{kg}$ $\mathrm{BB} /$ hari). Sedangkan antara kelompok kontrol sehat (K1) dengan kelompok perlakuan 2 (P2) dan kelompok kontrol sakit (K2) dengan kelompok perlakuan 1 (P1) tidak terdapat perbedaan yang bermakna. Hal ini menunjukkan bahwa pada dosis $200 \mathrm{mg} / \mathrm{kgBB} / \mathrm{hari}$ ekstrak buah kersen menunjukkan efek peningkatan berat testis yang lebih tinggi daripada dosis $100 \mathrm{mg} / \mathrm{kgBB} /$ hari.

\section{DISKUSI}

Studi ini menunjukkan bahwa terdapat perbedaaan yang bermakna rasio berat testis antar kelompok. Berdasarkan rerata kenaikan berat badan dan berat testis hewan coba yang terendah yaitu pada kelompok kontrol sakit (K2), kemudian diikuti P1 dan P2, sedangkan yang tertinggi yaitu pada kelompok $\mathrm{K} 1$, hal ini menunjukkan bahwa pemberian ekstrak buah kersen dapat mempengaruhi peningkatan berat badan dan berat testis pada tikus yang di papar asap rokok. Pemberian ekstrak buah kersen dosis 200mg/kgBB/hari ekstrak buah kersen menunjukkan efek peningkatan berat badan dan berat testis yang lebih tinggi daripada dosis $100 \mathrm{mg} / \mathrm{kgBB} /$ hari.

Hasil uji statistik menunjukkan perbedaan rasio berat testis yang bermakna antara kelompok kontrol sehat (K1) dengan kelompok kontrol sakit (K2), kelompok kontrol sehat (K1) dengan perlakuan 1 (P1), serta antara kelompok kontrol sakit (K2) dengan perlakuan $2(\mathrm{P} 2)$, serta tidak adanya Perbedaan yang bermakna antara kelompok kontrol sehat (K1) dengan kelompok perlakuan 2 (P2) dan kelompok kontrol sakit (K2) dengan kelompok perlakuan 1 (P1), hal ini menunjukkan bahwa tidak ada perbedaan yang antara kelompok sehat dengan kelompok yang diberi ekstrak buah kersen dosis 200mg/kgBB/hari, dan tidak ada perbedaan yang bermakna antara kelompok sakit dengan kelompok yang diberi ekstrak buah kersen dosis $100 \mathrm{mg} / \mathrm{kgBB} / \mathrm{hari}$.

Rokok berpengaruh kepada kualitas dan kuantitas sperma. Pada kasus-kasus infertilitas, hasil analisis semen menunjukkan bahwa infertilitas banyak disebabkan oleh kelainan konsentrasi, disusul dengan kelainan morfologi dan motilitas dari sperma. Asap 
rokok yang dihirup seseorang mengandung komponen gas dan partikel. Komponen gas dan partikel ini sangat berpotensi untuk menimbulkan radikal bebas. Radikal bebas adalah molekul yang mempunyai atom dengan elektron yang tidak berpasangan. Radikal bebas tidak stabil dan mempunyai reaktivitas yang tinggi. Reaktivitasnya dapat merusak tipe makromolekul seluler termasuk karbohidrat, protein, lipid dan asam nukleat. ${ }^{6}$

Sebuah studi menyatakan bahwa kandungan asap rokok meningkatkan ROS dan menurunkan antioksidan di cairan semen sehingga lebih rentan mengalami infertilitas karena meningkatnya produksi radikal bebas di dalam sperma, menyebabkan kerusakan DNA dan apoptosis sel sperma. Radikal bebas yang berasal dari partikel gas rokok juga menyebabkan terjadinya aglutinasi sperma sehingga berakibat terhadap menurunnya motilitas sperma. ${ }^{6}$

Buah kersen mengandung antioksidan antara lain vitamin $\mathrm{C}$, vitamin $\mathrm{E}$, fenol, flavonoid dan antosianin.10 Vitamin $C$, vitamin $\mathrm{E}$, betakaroten dan golongan flavonoid merupakan antioksidan yang digunakan sebagai pemutus rantai (chainbreaking antioxidant). ${ }^{8,9}$ Pigmen antosianin juga dapat bertindak sebagai antioksidan. Adanya kemampuan antosianin untuk memangsa radikal bebas yang langsung berasal dari asap rokok maupun radikal bebas yang timbul akibat respon inflamasi, maka antosianin dapat menekan terjadinya peroksidasi lipid. Antosianin dengan cepat dapat mengikat ion logam untuk membentuk komplek antosianin-logam yang stabil.

Hal tersebut menjelaskan bahwa antosianin mengikat logam transisi $\mathrm{Fe}^{2+}$ sehingga dapat dicegah terjadinya pembentukan reaksi hidroksil yang sangat toksik dan reaktif. $^{12}$ Flavonoid memiliki fungsi sebagai antioksidan primer, chelators dan superoxide anion scavengers, serta memiliki aktivitas antioksidan yang lebih kuat dalam melawan peroxy radicals dibandingkan dengan vitamin $\mathrm{E}$, vitamin $\mathrm{C}$ dan glutathione. $^{13}$

Tabel 1. Data deskriptif rerata berat badan, berat testis dan rasio berat testis pada tiap kelompok

\begin{tabular}{|c|c|c|c|c|c|c|}
\hline \multirow[t]{2}{*}{ Kelompok } & \multicolumn{2}{|c|}{$\begin{array}{c}\text { Rerata berat badan } \\
\text { (gram) }\end{array}$} & \multicolumn{2}{|c|}{$\begin{array}{c}\text { Rerata berat testis } \\
\text { (gram) }\end{array}$} & \multirow{2}{*}{$\begin{array}{l}\text { Rasio } \\
\text { berat } \\
\text { testis }\end{array}$} & \multirow[t]{2}{*}{$\begin{array}{l}\text { Standar } \\
\text { deviasi }\end{array}$} \\
\hline & Sebelum & Sesudah & Kanan & Kiri & & \\
\hline Kontrol 1 & 159 & 191 & 2,84 & 2,82 & 0,031 & \multirow{4}{*}{0,0049} \\
\hline Kontrol 2 & 201 & 202 & 1,94 & 1,94 & 0,019 & \\
\hline Perlakuan 1 & 180 & 204 & 2,46 & 2,48 & 0,024 & \\
\hline Perlakuan 2 & 171 & 200 & 2,77 & 2,72 & 0,028 & \\
\hline
\end{tabular}

Berdasarkan penelitian sebelumnya, saponin, yang tergolong dalam steroid serta senyawa flavonoid dan tannin yang diberikan secara in vitro, dapat meningkatkan motilitas sperma. Selain itu, ekstrak saponin dari Turnera diffusa dan Pfaffia paniculata dapat meningkatkan performa kopulasi secara seksual dari tikus yang dikondisikan menjadi 
tidak efektif dalam kemampuan sexualnya. ${ }^{14}$ Kandungan senyawa steroid dan flavonoid diketahui berkontribusi terhadap peningkatan kualitas sperma. ${ }^{7}$ Kandungan senyawa steroid dan flavonoid yang diketahui berkontribusi terhadap peningkatan kualitas sperma. $^{7}$
Adanya kandungan berbagai antioksidan dalam ekstrak buah kersen mampu melawan radikal bebas dari asap rokok sehingga mampu meningkatkan rasio berat testis yang dipapar asap rokok.

Tabel 2. Perbedaan rasio berat testis antara kelompok perlakuan dan kelompok kontrol dengan One Way ANOVA Test dan Post Hoc Multiple Comparison Test

\begin{tabular}{cccccc}
\hline & \multicolumn{4}{c}{ Post Hoc Multiple Comparison Test } & One Way ANOVA \\
\cline { 2 - 4 } & Kontrol 1 & Kontrol 2 & Perlakuan 1 & Perlakuan 2 & Test \\
\hline Kontrol 1 & - & $\rho=0.03^{*}$ & $\rho=0.016^{*}$ & $\rho=0.161$ & \\
Kontrol 2 & $\rho=0.03^{*}$ & - & $\rho=0.147$ & $\rho=0.19$ & \\
Perlakuan 1 & $\rho=0.016^{*}$ & $\rho=0.147$ & - & $\rho=0.159$ & $\rho=0.013^{*}$ \\
Perlakuan 2 & $=\rho 0.161$ & $\rho=0.19$ & $\rho=0.159$ & - & \\
\hline$P<0$ 05 (signifikan) & & & &
\end{tabular}

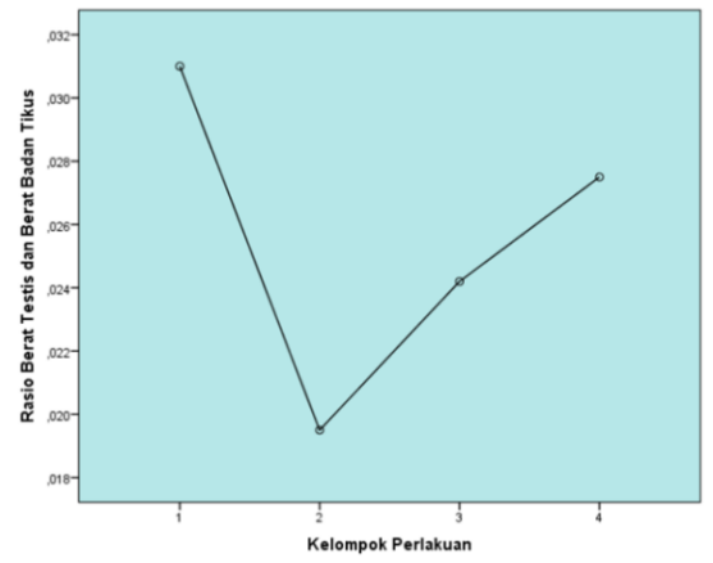

Gambar 2. Perbandingan rasio berat testis antar kelompok 


\section{KESIMPULAN}

Pemberian ekstrak buah kersen dapat meningkatkan rasio berat testis pada tikus yang di papar asap rokok, walaupun secara statistik tidak bermakna. Buah kersen memiliki potensi sebagai antioksidan, sehingga perlu dilakukan penelitian lebih lanjut antara lain meliputi evaluasi dosis pemberiannya.

\section{DAFTAR PUSTAKA}

1. WHO report on tobacco epidemic. 2008. Available from: URL: http://www.int/entity/tobacco.

Accessed Agst 3, 2011.

2. Muhammad I. Efek antioksidan vitamin c terhadap tikus (Rattus norvegicus L) jantan akibat pemaparan asap rokok. Tesis. Bandung. 2009.

3. Diken H, Kelle M, Tomer C, Denuz B, Baylan Y, Permet A. Effects of cigarrete smoking on blood antioxidant status in short-term and long-term smokers. Turk J Med Sci. 2001. (31)553-557

4. Drath DB, Karnovsky ML, Huber GL. Tobacco smoke. Effects on pulmonary host defense inflammation. USA.1979;3(3):281-8

5. Rima A, Suradi, Surjanto E dan Yunus F. Korelasi antara jumlah makrofa, neutrofil dan kadar enzim matrix metalloproteinase (MMP)-9 pada cairan kurasan bronkial perokok. Surakarta. J Respir Indo. 2007.;27 (3)3

6. Musfiroh M, Rifki M, Noor W. Pengaruh minyak nigella sativa terhadap kualitas spermatozoa tikus wistar yang terpapar asap rokok. $J$ Indon Med Assoc. 2012. Volume 62, Nomor: 5.

7. Musfirah Y, Bachri MS, Nurani LH. Potensi ekstrak etanol $70 \%$ akar saluang balum (Lavanga sarmentosa blume kurz) terhadap kualitas dan viabilitas sperma mencit. Pharmaciana. 2016. Vol.6, No.2, November, Hal. 131-138

8. Crystal RG. Biologi of free radicals, introduction. Am J Med. 1991. 91:15.

9. Noguci N, Niki E. Chemistry of active oxygen species and antioxidationts in antioxidant status, diet, nutrition, nad health. Edited by Papas AM. CRC Press. 1999. New York. p. 3-37

10. Gomathi R, Anusuya N, Manian S. A dietary antioxidant supplementation of jamaican cherries (muntingia calabura 1) attenuates inflammatory related disorders. Food Sci. Biotechnol. 2013;22(3): 787-794

11. World Health Organization. Global alliance against chronic respiratory diseases (GARD). General Meeting Report; May 30-31; Istanbul, Turkey. Geneva: WHO; 2008.

12. Miguel MG. Antioxidant activity of medicinal and aromatic plants : A review. Flavour and Fragrance Journal . 2010; 25(5): 291-312.

13. Kormin, S. The effect of heat processing on triterpene glycosides and antioxidant activity of herbal pegaga (centella asiatica 1. Urban) drink. (Tesis). Kuala Lumpur : Universiti Teknologi Malaysia. 2005.

14. Lefaan PN. Pengaruh infusa rumput kebar (Biophytum petersianum) terhadap spermatogenesis mencit (Mus musculus). JSV. 2014: 32 (1), Juli 